\title{
FGF18 wt Allele
}

National Cancer Institute

\section{Source}

National Cancer Institute. FGF18 wt Allele. NCI Thesaurus. Code C153048.

Human FGF18 wild-type allele is located in the vicinity of 5q35.1 and is approximately 38 $\mathrm{kb}$ in length. This allele, which encodes fibroblast growth factor 18 protein, plays a role in promoting cell proliferation in the small intestine and liver. 